\title{
Isolation and Structural Characterization of the Milled Wood Lignin, Dioxane Lignin, and Cellulolytic Lignin Preparations from Brewer's Spent Grain
}

\author{
Jorge Rencoret, ${ }^{\dagger}$ Pepijn Prinsen, ${ }^{\dagger}$ Ana Gutiérrez, ${ }^{\dagger}$ Ángel T. Martínez, ${ }^{\ddagger}$ and José C. del Río* ${ }^{\dagger}$ \\ ${ }^{\dagger}$ Instituto de Recursos Naturales y Agrobiología de Sevilla (IRNAS), CSIC, P.O. Box 1052, E-41080 Seville, Spain \\ ${ }^{*}$ Centro de Investigaciones Biológicas (CIB), CSIC, Ramiro de Maeztu 9, E-28040 Madrid, Spain
}

ABSTRACT: The structure of the lignin from brewer's spent grain (BSG) has been studied in detail. Three different lignin preparations, the so-called "milled-wood" lignin (MWL), dioxane lignin (DL), and cellulolytic lignin (CEL), were isolated from BSG and then thoroughly characterized by pyrolysis GC/MS, 2D-NMR, and derivatization followed by reductive cleavage (DFRC). The data indicated that BSG lignin presents a predominance of guaiacyl units (syringyl/guaiacyl ratio of 0.4-0.5) with significant amounts of associated $p$-coumarates and ferulates. The flavone tricin was also present in the lignin from BSG, as also occurred in other grasses. 2D-NMR (HSQC) revealed that the main substructures present are $\beta$-O-4' alkyl-aryl ethers (77-79\%) followed by $\beta-5^{\prime}$ phenylcoumarans $(11-13 \%)$ and lower amounts of $\beta-\beta^{\prime}$ resinols $(5-6 \%)$ and $5-5^{\prime}$ dibenzodioxocins $(3-5 \%)$. The results from 2D-NMR (HMBC) and DFRC indicated that $p$-coumarates are acylating the $\gamma$-carbon of lignin side chains and are mostly involved in condensed structures. DFRC analyses also indicated a minor degree of $\gamma$-acylation with acetate groups, which takes place preferentially on $\mathrm{S}$ lignin (6\% of $\mathrm{S}$ units are acetylated) over $\mathrm{G}$ lignin (only $1 \%$ of $\mathrm{G}$ units are acetylated).

KEYWORDS: brewer's spent grain, lignin, Py-GC/MS, TMAH, HSQC, DFRC

\section{INTRODUCTION}

Brewer's spent grain (BSG) is the solid waste generated during the brewing process and comprises the husk-pericarp-seed coat layers that covered the starting barley (Hordeum vulgare L.) grain. ${ }^{1-4}$ BSG accounts for around $30 \%(w / w)$ of the barley grain, making it a readily available high-volume and low-cost byproduct within the brewing industry that can be regarded as a potentially valuable resource for the production of new addedvalue products. ${ }^{1,2}$ Although BSG is produced in important amounts from brewing companies worldwide, with an estimated production of around 30 million tons per year, ${ }^{5}$ the major part of these residues remains mostly underexploited.

BSG is a lignocellulosic material that is primarily composed of cellulose (17-25\%), hemicelluloses (25-35\%), protein (15-24\%), lignin (8-28\%), and lower amounts of lipids $(10 \%) \cdot{ }^{1-6}$ Due to the high amounts of proteins and fibers, BSG has been predominantly used as animal feed. However, there is a trend nowadays for the more efficient utilization of the lignocellulosic residues generated from agro-forest and alimentary industries as feedstocks to produce new valueadded products in the context of the so-called lignocellulosic biorefinery. In this context, the development of new techniques and procedures for a more appropriate valorization and industrial exploitation of this agro-industrial waste is of major importance because BSG is widely available at low cost and in large amounts.

Recent studies regarding the valorization and potential uses of BSG indicate that it could be considered as an important feedstock for the production of new products such as xylitol, lactic acid, and hydroxycinnamic acids or used as a growth medium for microorganisms and enzyme production, for paper manufacturing, or even for energy production, including the production of second-generation bioethanol, among others. ${ }^{1,2,7,8}$ However, for an appropriate valorization of BSG as a source of added-value products and to explore newer applications and maximizing the use of existing technologies, a comprehensive characterization of the different components of BSG is of high interest. Previous studies have reported the composition of carbohydrates, proteins, lipids, and p-hydroxycinnamic acids in BSG. ${ }^{4-6,9-11}$ However, studies regarding the composition of the lignin polymer in BSG have been insufficient and mostly restricted to its interactions with gastrointestinal microbiota ${ }^{12,13}$ or to its recovery from the black liquors after alkaline pulping. ${ }^{7}$ It is known that the content and composition of the lignin polymer play a decisive role in digestibility and delignification reactions and, therefore, the structural characterization of the lignin from BSG is an important step in the development of suitable methods for lignin depolymerization approaches. Moreover, detailed knowledge of the lignin polymer in BSG will help in the development of lignin-based high-added-value products from this waste material.

The lignin polymer is a complex macromolecule synthesized mainly from three $p$-hydroxycinnamyl alcohols, namely, $p$ coumaryl, coniferyl, and sinapyl alcohols, differing in their degree of methoxylation. These monolignols give rise to the $p$ hydroxyphenyl $(\mathrm{H})$, guaiacyl $(\mathrm{G})$, and syringyl (S) units, respectively, producing a variety of structures and linkages within the lignin polymer. ${ }^{14,15}$ Moreover, $p$-hydroxycinnamates

Received: October 23, 2014

Revised: December 16, 2014

Accepted: December 18, 2014

Published: December 18, 2014 
( $p$-coumarates and ferulates) also occur in the lignins from grasses, such as barley, with $p$-coumarates acylating the $\gamma$-OH of the lignin side chain and ferulates and diferulates acylating cell wall polysaccharides and participating in both polysaccharidepolysaccharide and lignin-polysaccharide cross-coupling reactions, in the latter case mainly forming ether linkages similar to those existing between lignin units. ${ }^{16}$

In this study, an in-depth and comprehensive characterization of the lignin polymer in BSG has been performed. Because there is no universal method for the isolation of native lignin and due to the difficulties of isolating a representative lignin preparation from a material such as BSG, different lignin isolation methods were used. For this purpose, different lignin preparations that can be seen as representative of the native lignin due to their relatively low structural modification, namely, "milled-wood" lignin (MWL), dioxane lignin (DL), and cellulolytic lignin (CEL), were isolated according to traditional lignin isolation procedures. ${ }^{17-19}$ The isolated lignin preparations were subsequently analyzed by using different analytical techniques, such as pyrolysis GC/MS (Py-GC/MS), in the absence and in the presence of tetramethylammonium hydroxide (TMAH) as methylating agent; 2D-NMR; and derivatization followed by reductive cleavage (DFRC). As far as we know, this is the first time that the detailed study of the structure of BSG lignin has been reported. Knowledge of the composition and structure of BSG lignin will help in maximizing the industrial utilization of this important agroindustrial waste.

\section{MATERIALS AND METHODS}

Samples. The BSG sample used in this study was taken from Adnams brewery (Southwold, UK) and was kindly provided by Prof. Craig B. Faulds (INRA, Marseille, France). The sample was the residue resulting from wort prepared from malted barley for ale brewing. Further information about the composition of this particular sample has been previously published. ${ }^{20}$ The BSG sample was lyophilized and milled using an IKA knife mill (Janke \& Kunkel, Staufen, Germany). Fifty grams of sample was successively extracted with acetone in a Soxhlet apparatus for $16 \mathrm{~h}$ and with hot water (100 $\mathrm{mL}, 3 \mathrm{~h}$ at $100{ }^{\circ} \mathrm{C}$ ). The Klason lignin content was determined as the residue after sulfuric acid hydrolysis of the pre-extracted material according to TAPPI method T222 om- $8 .{ }^{21}$ The Klason lignin content was then corrected for proteins, determined from the $\mathrm{N}$ content obtained by CHN elemental analysis in a CHNS-932 Elemental Analyzer (LECO Corp., St. Joseph, MI, USA) and using a 6.25 factor, ${ }^{22}$ and ashes. The acid-soluble lignin content was estimated, after the insoluble lignin was filtered off, by UV spectroscopy at $205 \mathrm{~nm}$ wavelength using an extinction coefficient of $110 \mathrm{~L} / \mathrm{cm} / \mathrm{g}$. Holocellulose was isolated from pre-extracted BSG by delignification during $4 \mathrm{~h}$ using the acid chlorite method. ${ }^{23}$ The content of $\alpha$-cellulose was determined by removing the hemicelluloses from the holocellulose by alkali extraction. ${ }^{23}$ Finally, the ash content was determined gravimetrically after $6 \mathrm{~h}$ of heating at $575^{\circ} \mathrm{C}$. Three replicates were used for each sample.

Isolation of "Milled-Wood Lignin". The MWL was isolated from the BSG sample according to the classical protocol. ${ }^{17}$ Around $40 \mathrm{~g}$ of extractives-free sample was ball-milled in a PM100 planetary ball mill (Restch, Haan, Germany) at $400 \mathrm{rpm}$ for $36 \mathrm{~h}$ in an agate jar and using agate balls $(20 \times 20 \mathrm{~mm})$. The total ball-milling time was $5 \mathrm{~h}$, with 5 min breaks after every $5 \mathrm{~min}$ of milling. The ball-milled powder was subsequently extracted with dioxane/water, 9:1 (v/v), using $20 \mathrm{~mL}$ of solvent/g of milled sample for $12 \mathrm{~h}$ under agitation, the solution was centrifuged, and the supernatant was evaporated to dryness in a rotary evaporator at $40{ }^{\circ} \mathrm{C}$. The residue obtained (raw MWL) was then redissolved into a solution of acetic acid/water, 9:1 (v/v) $(25 \mathrm{~mL}$ of solvent/g of raw MWL). The lignin was then precipitated into cold water and separated by centrifugation, milled in an agate mortar, and subsequently dissolved in 1,2-dichloroethane/ethanol, 2:1 (v/v). The mixture was centrifuged to eliminate any insoluble material. The lignin in the supernatant was precipitated in diethyl ether and recovered by centrifugation. This residue was then suspended in diethyl ether overnight, centrifuged, and finally suspended in petroleum ether. The final purified MWL sample was washed with $n$-hexane, recovered by centrifugation, and dried under nitrogen. The final yield was around $10 \%$ of the original Klason lignin content.

Isolation of Dioxane Lignin. The isolation of the DL was performed by acidolysis by the dioxane method according to a previously published procedure, ${ }^{18}$ with some minor modifications. Fourteen grams of dry extractives-free (by Soxhlet extraction during 16 $\mathrm{h}$ with acetone and subsequent extraction with water at $100{ }^{\circ} \mathrm{C}$ ) ballmilled BSG sample was refluxed for $40 \mathrm{~min}$ (3 times) with $150 \mathrm{~mL}$ of $0.05 \mathrm{M} \mathrm{HCl}$ in dioxane/water, 82:18 (v/v), under nitrogen. The lignin was then filtered and washed with dioxane/water, 82:18 (v/v). The filtrate was evaporated in a rotary evaporator at $40{ }^{\circ} \mathrm{C}$, and then the lignin was precipitated in water. The precipitated lignin was then centrifuged and freeze-dried. After freeze-drying, the lignins were Soxhlet extracted with hexane for $8 \mathrm{~h}$ to remove lipid contaminants. The yield of DL was around 50\% (based on the Klason lignin content).

Isolation of Cellulolytic Lignin. CEL preparations were isolated by enzymatically hydrolyzing the polysaccharides according to the protocol previously described. ${ }^{19}$ For this purpose, we used Cellulysin (Calbiochem-Behring Corp., La Jolla, CA, USA), a crude cellulase preparation from Trichoderma viride that also contains hemicellulase activities. Its activity was $\geq 10000$ units $/ g$, estimated as reducing sugars (glucose equivalents) released from a paper filter at $40^{\circ} \mathrm{C}, \mathrm{pH}$. The extractives-free ball-milled material $(200 \mathrm{mg})$ was suspended in 20 $\mathrm{mM} \mathrm{NaOAc}$ buffer $(30 \mathrm{~mL}, \mathrm{pH} 5.0)$ in a $50 \mathrm{~mL}$ centrifuge tube, $8 \mathrm{mg}$ of Cellulysin was added, and the reaction slurry was incubated at $30^{\circ} \mathrm{C}$ for $48 \mathrm{~h}$. The solids were recovered by centrifugation $\left(8000 \mathrm{rpm}, 4{ }^{\circ} \mathrm{C}\right.$, $20 \mathrm{~min}$ ), and the process was repeated twice with fresh buffer and enzyme. The lignin was finally recovered by filtration, washed with water, and then lyophilized. The yield of CEL was around 105\% of the Klason lignin, indicating the presence of some contaminants in this lignin preparation.

Analytical Pyrolysis. The pyrolysis of the different lignin preparations (ca. $0.1 \mathrm{mg}$ ) was carried out in a 3030 microfurnace pyrolyzer (Frontier Laboratories Ltd., Fukushima, Japan) connected to a GC 7820A (Agilent Technologies, Inc., Santa Clara, CA, USA) and an Agilent 5975 mass selective detector (EI at $70 \mathrm{eV}$ ). The column used was a $60 \mathrm{~m} \times 0.25 \mathrm{~mm}$ i.d., $0.25 \mu \mathrm{m}$ film thickness, DB-1701 (J\&W Scientific, Folsom, CA, USA). The pyrolysis was performed at $500{ }^{\circ} \mathrm{C}$. The oven temperature was programmed from $45^{\circ} \mathrm{C}(4 \mathrm{~min})$ to $280{ }^{\circ} \mathrm{C}$ at a heating rate of $4{ }^{\circ} \mathrm{C} / \mathrm{min}$ and held for $10 \mathrm{~min}$. The carrier gas was helium at $2 \mathrm{~mL} / \mathrm{min}$. For Py/TMAH, around $0.1 \mathrm{mg}$ of sample was mixed with $0.5 \mu \mathrm{L}$ of TMAH $(25 \%, \mathrm{w} / \mathrm{w}$, in methanol), and the pyrolysis was performed as described above. The released phenolic compounds were identified by comparison of their mass spectra with those present in the Wiley and NIST libraries and those reported in the literature ${ }^{24,25}$ and, when possible, by comparison with retention time and mass spectra of authentic standards. Peak molar areas for each lignin-derived phenolic compound were calculated, the summed areas were normalized, and the data for two repetitive analyses were averaged and expressed as percentages. The relative standard deviation was $<5 \%$. The response factors for most of the lignin-derived phenols released were practically identical, except for vanillin, ${ }^{26}$ which is a minor peak here. Therefore, no attempt was made to calculate the response factor for every compound released.

NMR Spectroscopy. 2D-NMR spectra of the isolated lignin preparations were recorded at $25{ }^{\circ} \mathrm{C}$ on an AVANCE III $500 \mathrm{MHz}$ instrument (Bruker, Karlsruhe, Germany) equipped with a cryogenically cooled $5 \mathrm{~mm}$ TCI gradient probe with inverse geometry. The lignin preparations $(40 \mathrm{mg})$ were dissolved in $0.75 \mathrm{~mL}$ of dimethyl sulfoxide (DMSO) $-d_{6}$. The central solvent peak was used as the internal reference (DMSO, $\delta_{\mathrm{C}} / \delta_{\mathrm{H}} 39.5 / 2.49$ ). The heteronuclear single-quantum coherence (HSQC) experiment used Bruker's 
"hsqcetgpsisp2.2" adiabatic pulse program with spectral widths from 0 to $10 \mathrm{ppm}(5000 \mathrm{~Hz})$ and from 0 to $165 \mathrm{ppm}(20625 \mathrm{~Hz})$ for the ${ }^{1} \mathrm{H}$ and ${ }^{13} \mathrm{C}$ dimensions. The number of transients was 64 , and 256 time increments were always recorded in the ${ }^{13} \mathrm{C}$ dimension. The ${ }^{1} J_{\mathrm{CH}}$ used was $145 \mathrm{~Hz}$. Processing used typical matched Gaussian apodization in the ${ }^{1} \mathrm{H}$ dimension and squared cosine-bell apodization in the ${ }^{13} \mathrm{C}$ dimension. Prior to Fourier transformation, the data matrices were zero-filled to 1024 points in the ${ }^{13} \mathrm{C}$ dimension. For heteronuclear multiple bond correlation (HMBC) acquisition experiments, the longrange $J$-coupling evolution time used was $80 \mathrm{~ms}$.

2D-NMR correlation signals were assigned by literature comparison. $^{27-30} \mathrm{~A}$ semiquantitative analysis of the HSQC signals was performed using Bruker's Topspin 3.1 processing software. Integration of signals was performed separately for the different regions of the spectra corresponding to chemically analogous $\mathrm{C}-\mathrm{H}$ pairs with similar ${ }^{1} J_{\mathrm{CH}}$ coupling values. The relative abundances of side chains involved in the different interunit linkages were estimated in the aliphatic oxygenated region from the $\mathrm{C}_{\alpha}-\mathrm{H}_{\alpha}$ correlations, except for $\alpha$-oxidized $\beta$-O-4 substructures $\left(\mathrm{A}_{\text {ox }}\right)$, for which $\mathrm{C}_{\beta}-\mathrm{H}_{\beta}$ correlations had to be used. In the aromatic/unsaturated region, $\mathrm{C}_{2}-\mathrm{H}_{2}$ correlations from $\mathrm{H}$, $\mathrm{G}$, and $\mathrm{S}$ lignin units and from $p$-coumarates and ferulates were used to estimate their relative abundances.

DFRC (Derivatization followed by Reductive Cleavage). The DFRC degradation was performed according to the protocol previously developed. ${ }^{31-33}$ Lignins $(10 \mathrm{mg})$ were mixed with acetyl bromide in acetic acid, 8:92 (v/v), and stirred at $50{ }^{\circ} \mathrm{C}$ for $2 \mathrm{~h}$. The solvents and excess of acetyl bromide were removed by rotary evaporation at reduced pressure. The products were then dissolved in dioxane/acetic acid/water, 5:4:1 (v/v/v), $50 \mathrm{mg}$ of powdered $\mathrm{Zn}$ was added, and the mixture was stirred at room temperature for $40 \mathrm{~min}$. After completion, the reaction mixture was transferred into a separation funnel with dichloromethane and saturated ammonium chloride. The aqueous phase was adjusted to $\mathrm{pH}<3$ by adding $3 \%$ $\mathrm{HCl}$, the mixture vigorously mixed, and the organic layer separated. The water phase was extracted twice more with dichloromethane. The combined dichloromethane fractions were dried over anhydrous $\mathrm{Na}_{2} \mathrm{SO}_{4}$, and the filtrate was evaporated on a rotary evaporator. The residue was then acetylated in $1.1 \mathrm{~mL}$ of dichloromethane containing $0.2 \mathrm{~mL}$ of acetic anhydride and $0.2 \mathrm{~mL}$ of pyridine for $1 \mathrm{~h}$. The acetylated lignin degradation products were collected after rotary evaporation of the solvents and analyzed by GC/MS using mass spectra and relative retention times to authenticate the DFRC monomers and their $p$-coumarate conjugates as described in previous papers. ${ }^{31-33}$ To investigate the occurrence of native acetylated lignin units, a modification of the standard DFRC method using propionylating instead of acetylating reagents (DFRC') was used in the present study. ${ }^{34-36}$

The GC/MS analyses were performed with a GCMS-QP2010 Ultra instrument (Shimadzu Co., Kyoto, Japan). The column used was a 30 $\mathrm{m} \times 0.25 \mathrm{~mm}$ i.d., $0.10 \mu \mathrm{m}$ film thickness, DB-5HT (J\&W Scientific). The oven was heated from $140{ }^{\circ} \mathrm{C}(1 \mathrm{~min})$ to $250{ }^{\circ} \mathrm{C}$ at $3{ }^{\circ} \mathrm{C} / \mathrm{min}$, then ramped at $10^{\circ} \mathrm{C} / \mathrm{min}$ to $300{ }^{\circ} \mathrm{C}$, and held for $10 \mathrm{~min}$ at the final temperature. The injector was set at $250{ }^{\circ} \mathrm{C}$, and the transfer line was kept at $300{ }^{\circ} \mathrm{C}$. Helium was used as the carrier gas at a rate of $1 \mathrm{~mL} /$ min. The DFRC compounds were identified on the basis of the mass spectra and relative retention times of authentic standards published previously. ${ }^{31,32}$ Quantitation of the released individual (acetylated and propionylated) monomers was performed using tetracosane as external standard and by assuming response factors similar to those of the acetylated monomers reported previously. ${ }^{30}$

\section{RESULTS AND DISCUSSION}

The abundance of the main constituents (namely, water-soluble material, lipids, Klason lignin, acid-soluble lignin, polysaccharides, proteins, and ash) of the BSG sample analyzed in this work is indicated in Table 1. Previously published data of this sample are also shown for comparison. The Klason lignin content estimated in this work was relatively low $(8.8 \%)$ compared to previous published data for the same sample (16-
Table 1. Abundance of the Main Constituents (Percent Dry Weight) of the Brewer's Spent Grain Sample ${ }^{a}$

\begin{tabular}{lccc}
\multicolumn{1}{c}{ constituent } & content $^{b}$ & $\begin{array}{c}\text { Robertson et al. } \\
(2010)^{4}\end{array}$ & $\begin{array}{c}\text { Faulds et al. } \\
(2008)^{20}\end{array}$ \\
$\begin{array}{l}\text { water-soluble } \\
\text { material }\end{array}$ & $8.3 \pm 1.0$ & nd & nd \\
lipids & $9.2 \pm 0.2$ & nd & 5.4 \\
Klason lignin & $8.8 \pm 0.9^{c}$ & 16.0 & 20.1 \\
acid-soluble lignin & $4.9 \pm 0.3$ & nd & nd \\
polysaccharides & $49.4 \pm 2.0$ & 43.3 & 51.0 \\
proteins & $14.5 \pm 1.0$ & 18.8 & 17.6 \\
ash & $4.9 \pm 0.1$ & nd & nd
\end{tabular}

${ }^{a}$ Data from other papers regarding the same sample are shown for comparison. ${ }^{4,20} b$ Average of three replicates. ${ }^{c}$ Corrected for proteins and ash.
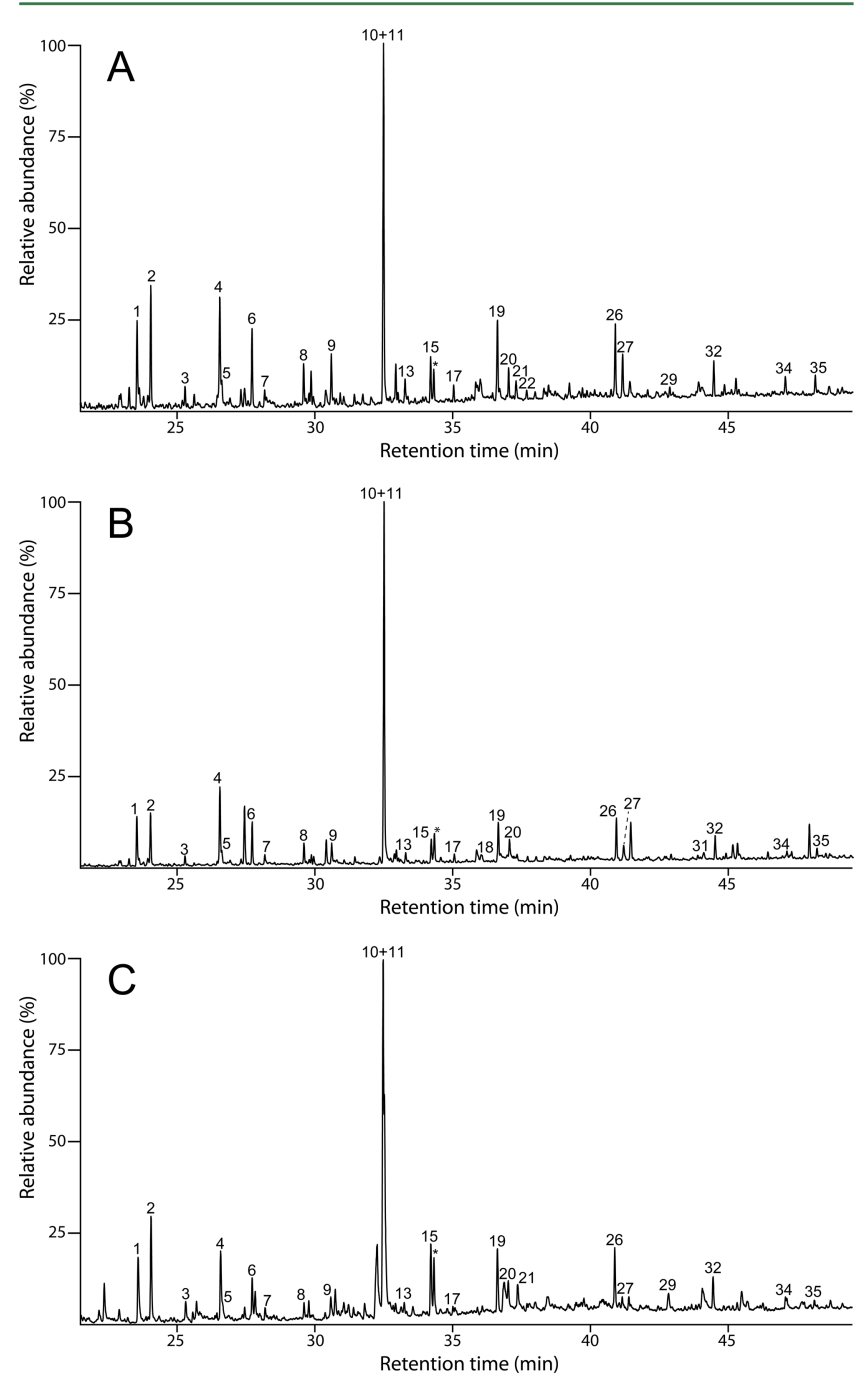

Figure 1. Py-GC/MS chromatograms of the different lignin preparations isolated from BSG: (A) MWL; (B) DL; (C) CEL. The identities and relative abundances of the lignin-derived phenolic compounds released are listed in Table 2. (*) $1 H$-Indole from proteins.

$20.1 \%)$. One of the main reasons for this discrepancy is that previous works did not consider the high amounts of proteins and ashes when the Klason lignin content was quantitated gravimetically and presented an uncorrected value. In our case, the uncorrected Klason lignin content amounted to ca. 13\%, 
Table 2. Identities and Relative Molar Abundances of the Lignin-Derived Compounds Released after Py-GC/MS of MWL, DL, and CEL Preparations Isolated from the BSG Sample

\begin{tabular}{|c|c|c|c|c|c|c|}
\hline no. & compound & $M_{\mathrm{w}}$ & origin $^{a}$ & MWL & $\mathrm{DL}$ & CEL \\
\hline 1 & phenol & 94 & $\mathrm{H} / \mathrm{Pr}$ & 9.1 & 7.9 & 8.2 \\
\hline 2 & guaiacol & 124 & G & 8.7 & 5.6 & 8.1 \\
\hline 3 & $\begin{array}{l}\text { 2-methylphenol } \\
\text { (o-cresol) }\end{array}$ & 108 & $\mathrm{H} / \mathrm{Pr}$ & 1.7 & 1.2 & 1.6 \\
\hline 4 & $\begin{array}{l}\text { 4-methylphenol } \\
(p \text {-cresol })\end{array}$ & 108 & $\mathrm{H} / \mathrm{Pr}$ & 11.3 & 10.6 & 6.4 \\
\hline 5 & $\begin{array}{l}\text { 3-methylphenol } \\
\text { ( } m \text {-cresol) }\end{array}$ & 108 & $\mathrm{H} / \mathrm{Pr}$ & 2.3 & 1.8 & 1.4 \\
\hline 6 & 4-methylguaiacol & 138 & G & 5.3 & 4.2 & 2.7 \\
\hline 7 & 2,4-dimethylphenol & 122 & $\mathrm{H} / \mathrm{Pr}$ & 1.1 & 1.1 & 0.8 \\
\hline 8 & 4-ethylphenol & 122 & $\mathrm{H} / \mathrm{Pr}$ & 3.0 & 2.3 & 1.1 \\
\hline 9 & 4-ethylguaiacol & 152 & G & 3.1 & 2.0 & 1.2 \\
\hline 10 & 4-vinylphenol & 120 & $\mathrm{H} / \mathrm{Pr} / \mathrm{PCA}$ & 10.4 & 21.8 & 23.0 \\
\hline 11 & 4-vinylguaiacol & 150 & G/FA & 15.5 & 20.5 & 21.6 \\
\hline 12 & 4-allylphenol & 134 & $\mathrm{H}$ & 0.2 & 0.2 & 0.2 \\
\hline 13 & eugenol & 164 & G & 1.6 & 1.0 & 0.7 \\
\hline 14 & 4-propylguaiacol & 166 & G & 0.5 & 0.2 & 0.2 \\
\hline 15 & syringol & 154 & $S$ & 2.7 & 2.3 & 4.8 \\
\hline 16 & $\begin{array}{l}\text { cis-4- } \\
\text { propenylphenol }\end{array}$ & 134 & $\mathrm{H}$ & 0.1 & 0.1 & 0.1 \\
\hline 17 & cis-isoeugenol & 164 & G & 0.9 & 0.5 & 0.4 \\
\hline 18 & $\begin{array}{l}\text { trans-4- } \\
\text { propenylphenol }\end{array}$ & 134 & $\mathrm{H}$ & 0.6 & 0.6 & 0.4 \\
\hline 19 & trans-isoeugenol & 164 & G & 5.0 & 2.7 & 4.2 \\
\hline 20 & 4-methylsyringol & 168 & $S$ & 1.5 & 1.7 & 1.6 \\
\hline 21 & vanillin & 152 & G & 1.3 & 0.6 & 1.6 \\
\hline 22 & 4-propinylguaiacol & 162 & G & 0.6 & 0.5 & 0.3 \\
\hline 23 & 4-propinylguaiacol & 162 & G & 0.5 & 0.4 & 0.3 \\
\hline 24 & 4-ethylsyringol & 182 & $S$ & 0.9 & 0.4 & 0.3 \\
\hline 25 & acetovanillone & 166 & G & 0.5 & 0.3 & 0.4 \\
\hline 26 & 4-vinylsyringol & 180 & $S$ & 3.7 & 3.3 & 3.2 \\
\hline 27 & guaiacylacetone & 180 & G & 2.5 & 1.4 & 0.6 \\
\hline 28 & 4-allylsyringol & 194 & $S$ & 0.4 & 0.8 & 0.4 \\
\hline 29 & $\begin{array}{l}\text { cis-4- } \\
\text { propenylsyringol }\end{array}$ & 194 & $S$ & 0.5 & 0.4 & 0.3 \\
\hline 30 & 4-propinylsyringol & 192 & $S$ & 0.3 & 0.2 & 0.1 \\
\hline 31 & 4-propinylsyringol & 192 & $S$ & 0.2 & 0.2 & 0.1 \\
\hline 32 & $\begin{array}{l}\text { trans-4- } \\
\text { propenylsyringol }\end{array}$ & 194 & $S$ & 1.7 & 1.6 & 1.7 \\
\hline 33 & syringaldehyde & 182 & $S$ & 0.3 & 0.1 & 0.4 \\
\hline 34 & acetosyringone & 196 & $S$ & 1.1 & 0.4 & 0.5 \\
\hline 35 & syringylacetone & 210 & $S$ & 0.7 & 0.7 & 0.4 \\
\hline 36 & propiosyringone & 210 & $S$ & 0.2 & 0.2 & 0.1 \\
\hline 37 & $\begin{array}{l}\text { syringyl vinyl } \\
\text { ketone }\end{array}$ & 208 & $S$ & 0.2 & 0.2 & 0.3 \\
\hline
\end{tabular}

${ }^{a} \mathrm{H}$, lignin $p$-hydroxyphenyl-type; $\mathrm{G}$, lignin guaiacyl-type; $\mathrm{S}$, lignin syringyl-type; PCA, $p$-coumarate; FA, ferulate; Pr, proteins. All G- and $S$-derived peaks were used for the estimation of the $S / G$ ratio, except 4-vinylguaiacol (which also arises from ferulates), and the analogous 4vinylsyringol.

but contained appreciable amounts of ashes (ca. 10\%) and proteins (ca. 20\%) that needed to be corrected. Therefore, it is important to stress the importance of correcting the Klason lignin content in BSG (and related samples) for proteins and ashes to avoid presenting overestimated values.

In this work, we have thoroughly studied the composition and structure of the lignin polymer of BSG. For this purpose,
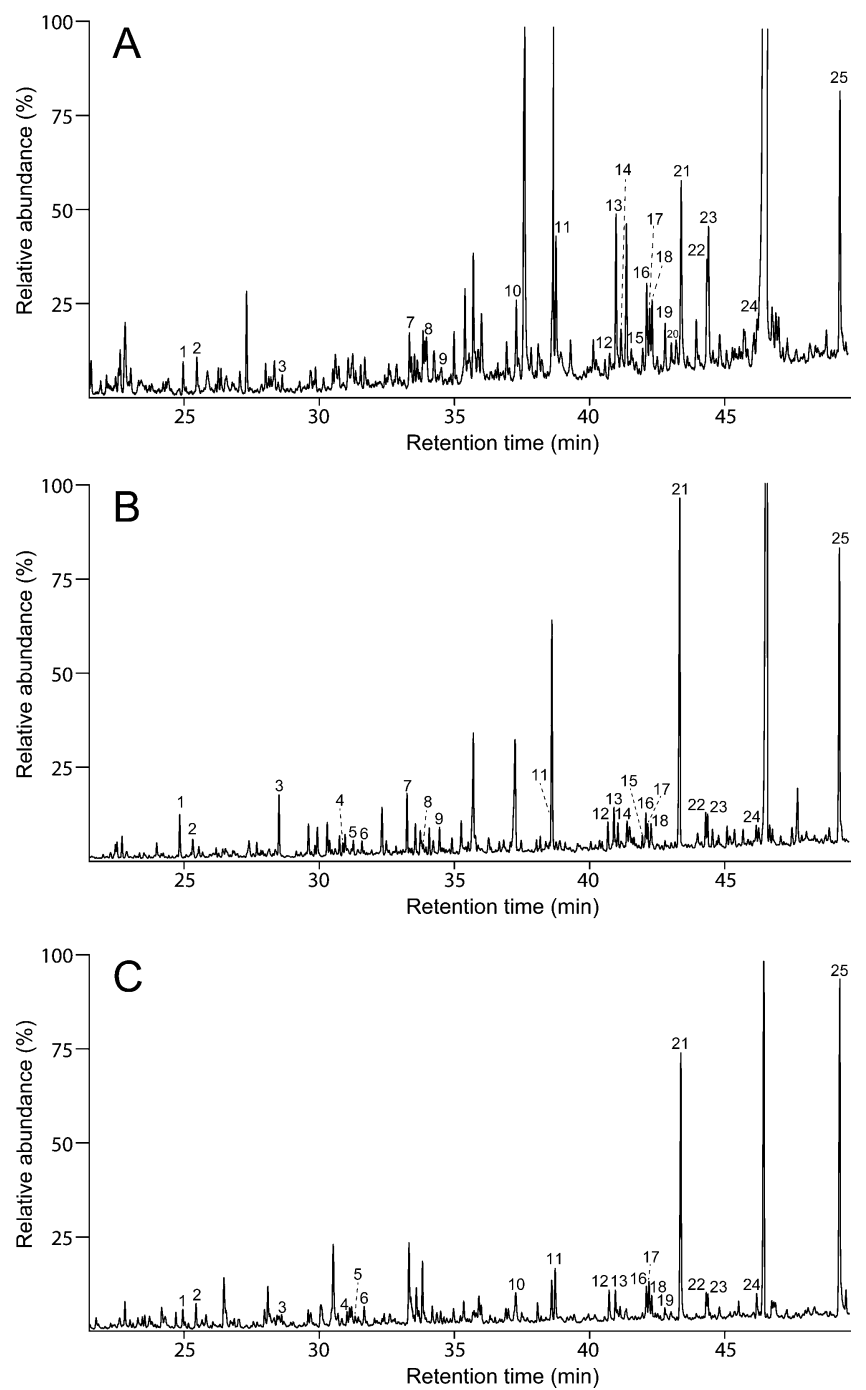

Figure 2. Py-TMAH-GC/MS chromatograms of the different lignin preparations isolated from BSG: (A) MWL; (B) DL; (C) CEL. The identities and relative abundances of the released lignin-derived compounds are listed in Table 3.

different lignin preparations, MWL, DL, and CEL, were isolated from the BSG sample selected for this study according to traditional lignin isolation procedures. ${ }^{17-19}$ However, it is well recognized that these lignin preparations, in particular MWL due to its low yield, represent only a part of the native lignin and may not be representative of the whole lignin present in the plant material. ${ }^{19,37,38}$ Indeed, these lignin preparations can also undergo some structural modifications during isolation, especially during extended milling. ${ }^{38,39}$ The yields of the lignin preparations isolated from the BSG sample varied from $10 \%$ (MWL) to $50 \%(\mathrm{DL})$ to $105 \%$ (CEL) of the Klason lignin content. However, and although these lignin preparations were purified as described, they still contained appreciable amounts of proteins (calculated from the $\mathrm{N}$ content), which accounted for $20 \%$ (MWL), $30 \%(\mathrm{DL})$, and $21 \%$ (CEL), that were difficult to remove and lipids, as shown in the NMR spectra. In any case, and despite the presence of impurities, it was still possible to get information about the structure of the lignin polymer. To obtain a detailed description of the structure of the BSG lignin, these lignin preparations were subsequently 
Table 3. Identities and Relative Molar Abundances of the Compounds Released after Pyrolysis in the Presence of TMAH of MWL, DL, and CEL Preparations Isolated from the BSG Sample

\begin{tabular}{|c|c|c|c|c|c|c|}
\hline no. & compound & $M_{\mathrm{w}}$ & origin $^{a}$ & MWL & $\mathrm{DL}$ & CEL \\
\hline 1 & 4-methoxystyrene & 134 & $\mathrm{H} / \mathrm{Pr}$ & 2.3 & 4.2 & 2.3 \\
\hline 2 & 1,2-dimethoxybenzene & 138 & G & 2.5 & 1.4 & 3.2 \\
\hline 3 & 3,4-dimethoxytoluene & 152 & G & 1.2 & 5.0 & 0.9 \\
\hline 4 & 4-methoxybenzaldehyde & 136 & $\mathrm{H} / \mathrm{Pr}$ & 2.7 & 1.3 & 1.6 \\
\hline 5 & 4-ethyl-1,2-dimethoxybenzene & 166 & G & 0.9 & 1.2 & 0.7 \\
\hline 6 & 1,2,3-trimethoxybenzene & 168 & $S$ & 1.5 & 0.9 & 2.2 \\
\hline 8 & 4-methoxybenzoic acid methyl ester & 166 & $\mathrm{H} / \mathrm{Pr}$ & 2.6 & 0.7 & 0.3 \\
\hline 9 & 3,4,5-trimethoxytoluene & 185 & $S$ & 0.7 & 1.9 & 1.2 \\
\hline 10 & 1,2-dimethoxy-4-propenylbenzene & 178 & G & 1.5 & 2.3 & 1.0 \\
\hline 11 & 3,4-dimethoxybenzaldehyde & 166 & G & 8.5 & 8.5 & 5.7 \\
\hline 12 & cis-3-(4-methoxyphenyl)-3-propenoic acid methyl ester & 192 & PCA & 0.7 & 1.9 & 3.0 \\
\hline 13 & 3,4-dimethoxybenzoic acid methyl ester & 196 & G & 9.2 & 2.5 & 2.4 \\
\hline 14 & 3,4-dimethoxyacetophenone & 180 & G & 2.9 & 1.8 & 1.0 \\
\hline 16 & cis-1-(3,4-dimethoxyphenyl)-2-methoxyethylene & 194 & G & 5.1 & 1.7 & 1.7 \\
\hline 17 & 3,4,5-trimethoxybenzaldehyde & 196 & $S$ & 3.1 & 1.3 & 3.0 \\
\hline 18 & trans-1-(3,4-dimethoxyphenyl)-2-methoxyethylene & 194 & G & 3.5 & 1.5 & 1.5 \\
\hline 19 & cis-1-(3,4-dimethoxyphenyl)-1-methoxyprop-1-ene & 208 & G & 1.9 & 0.5 & 0.9 \\
\hline 20 & trans-1-(3,4-dimethoxyphenyl)-1-methoxyprop-1-ene & 208 & G & 1.0 & 0.4 & 0.6 \\
\hline 21 & trans-3-(4-methoxyphenyl)-3-propenoic acid methyl ester & 192 & PCA & 13.6 & 27.2 & 26.8 \\
\hline 22 & 3,4,5-trimethoxyacetophenone & 210 & $S$ & 5.4 & 1.9 & 1.9 \\
\hline 23 & 3,4,5-trimethoxybenzoic acid methyl ester & 226 & $S$ & 6.8 & 1.6 & 1.5 \\
\hline 24 & cis-3-(3,4-dimethoxyphenyl)-3-propenoic acid methyl ester & 222 & FA & 1.3 & 1.0 & 1.8 \\
\hline \multirow[t]{3}{*}{25} & trans-3-(3,4-dimethoxyphenyl)-3-propenoic acid methyl ester & 222 & FA & 16.9 & 23.8 & 32.3 \\
\hline & & & $\mathrm{S} / \mathrm{G}$ ratio $=$ & 0.5 & 0.4 & 0.5 \\
\hline & & & $\mathrm{PCA} / \mathrm{FA}$ ratio $=$ & 0.8 & 1.1 & 0.8 \\
\hline
\end{tabular}

${ }^{a} \mathrm{H}$, lignin $p$-hydroxyphenyl type; G, lignin guaiacyl type; S, lignin syringyl type; PCA, $p$-coumarate; FA, ferulate; Pr, proteins.

analyzed by different analytical methodologies, including PyGC/MS, 2D-NMR, and DFRC.

Lignin Composition As Observed by Py-GC/MS. The different lignin preparations (MWL, DL, CEL) isolated from the BSG sample selected for this study were first analyzed by Py-GC/MS. The pyrograms are shown in Figure 1, and the identification and relative molar abundances of the released phenolic compounds are listed in Table 2. The pyrograms of the three lignin preparations were rather similar and released phenolic compounds that are derived from $p$-hydroxyphenyl $(\mathrm{H})$, guaiacyl $(\mathrm{G})$, and syringyl $(\mathrm{S})$ lignin units as well as from $p$-hydroxycinnamates ( $p$-coumarates and ferulates). The most predominant phenolic compounds released were 4-vinylphenol (10) and 4-vinylguaiacol (11), with important amounts of other compounds such as phenol (1), guaiacol (2), 4methylphenol (4), 4-methylguaiacol (6), syringol (15), transisoeugenol (19), 4-methylsyringol (20), 4-vinylsyringol (26), guaiacylacetone (27), and trans-4-propenylsyringol (32). Compounds 10 and 11 coelute together in the same chromatographic peak, and their relative abundances in this peak were estimated on the basis of the relative abundance of their respective characteristic fragments ions $(\mathrm{m} / z 91$ and 120 for 4-vinylphenol; $m / z 107,135$, and 150 for 4-vinylguaiacol).

The high levels of phenol (1), 4-methylphenol (4), and 4vinylphenol (10), together with the important amounts of $1 \mathrm{H}$ indole released from the different lignin preparations, seem to indicate that the major part of these phenolic compounds does not arise from $\mathrm{H}$-lignin structural units but from proteins, in agreement with the high content of protein impurities present in these lignin preparations as shown above. In addition, the high amounts of 4-vinylphenol (10) released upon pyrolysis from these lignin preparations, as also occurs in the lignins from other grasses, may also arise from $p$-coumarate esters that are acylating the lignin side chains and which decarboxylate efficiently under pyrolytic conditions. ${ }^{28,29,40,41}$ Similarly, 4vinylguaiacol (11), which is also present in high abundance among the pyrolysis products of the different BSG lignin preparations, might also arise from ferulates after decarboxylation upon pyrolysis. ${ }^{28,29,40,41}$ Therefore, 4-vinylphenol and 4vinylguaiacol cannot be used to determine the lignin $\mathrm{H}: \mathrm{G}: \mathrm{S}$ composition upon $\mathrm{Py}-\mathrm{GC} / \mathrm{MS}$ in the BSG lignin preparations because part of them does not arise from lignin structural units but from $p$-hydroxycinnamates or also from proteins in the case of 4-vinylphenol. An estimation of the S/G ratio was, however, obtained by using the molar areas of all the G- and S-derived compounds listed in Table 2, except for 4-vinylguaiacol, which also arises from ferulates, and its respective 4-vinylsyringol. The $S / G$ ratios thus calculated for the different BSG lignin preparations indicated a predominance of G- over S-lignin units, with a $S / G$ ratio in the range of $0.4-0.5$.

As stated above, the high amounts of 4-vinylphenol and 4vinylguaiacol released in the pyrograms point to the occurrence of important amounts of $p$-hydroxycinnamates ( $p$-coumarates and ferulates) in the BSG lignin preparations, as usually occurs in all grasses. The occurrence of $p$-hydroxycinnamates in the BSG lignin preparations was therefore assessed by pyrolysis in the presence of TMAH as methylating reagent. ${ }^{28,29,40,41} \mathrm{Py} /$ TMAH induces transesterification of the $p$-hydroxycinnamate 


\section{$\underline{\text { Inter-unit linkages region }}$}
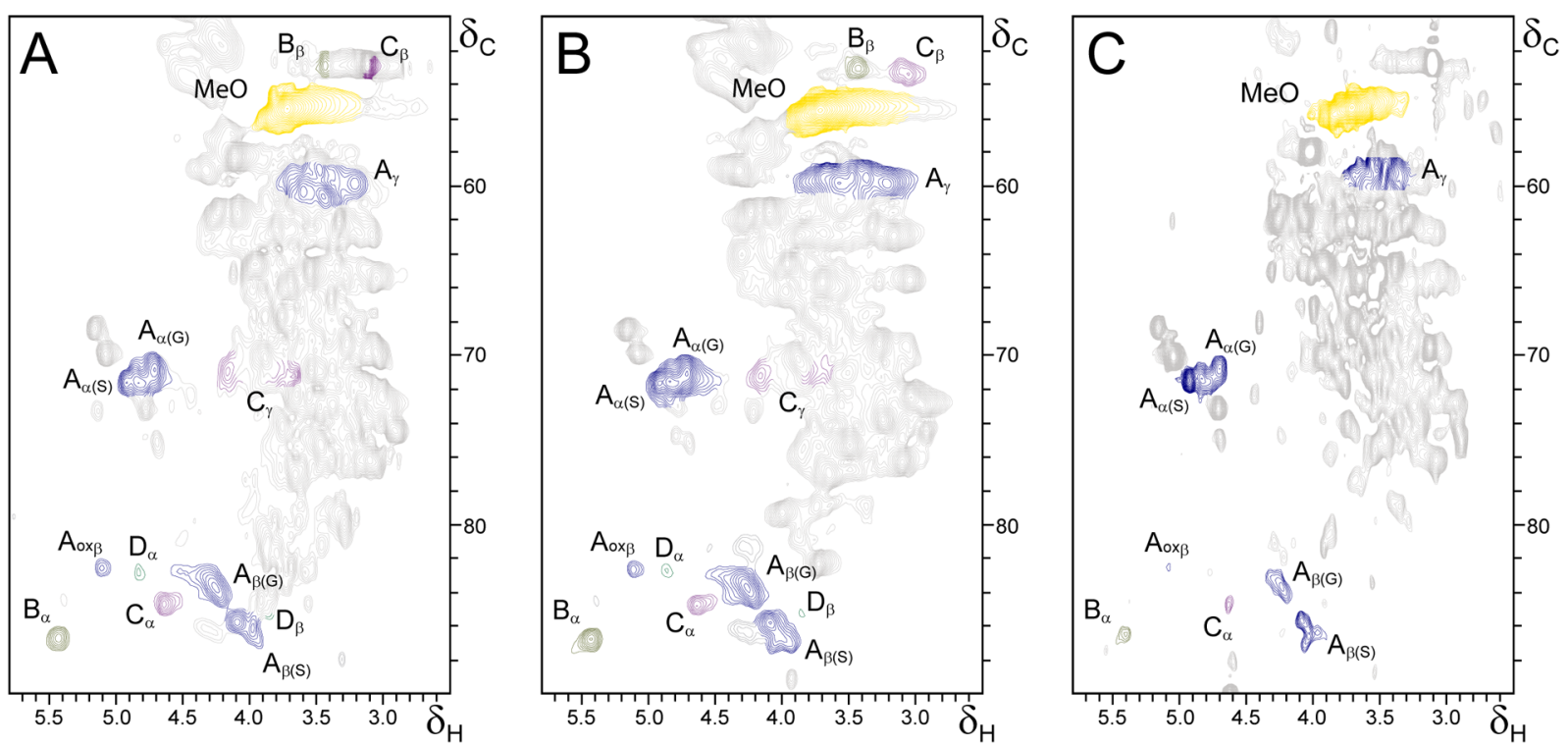

\section{Aromatic/unsaturated region}
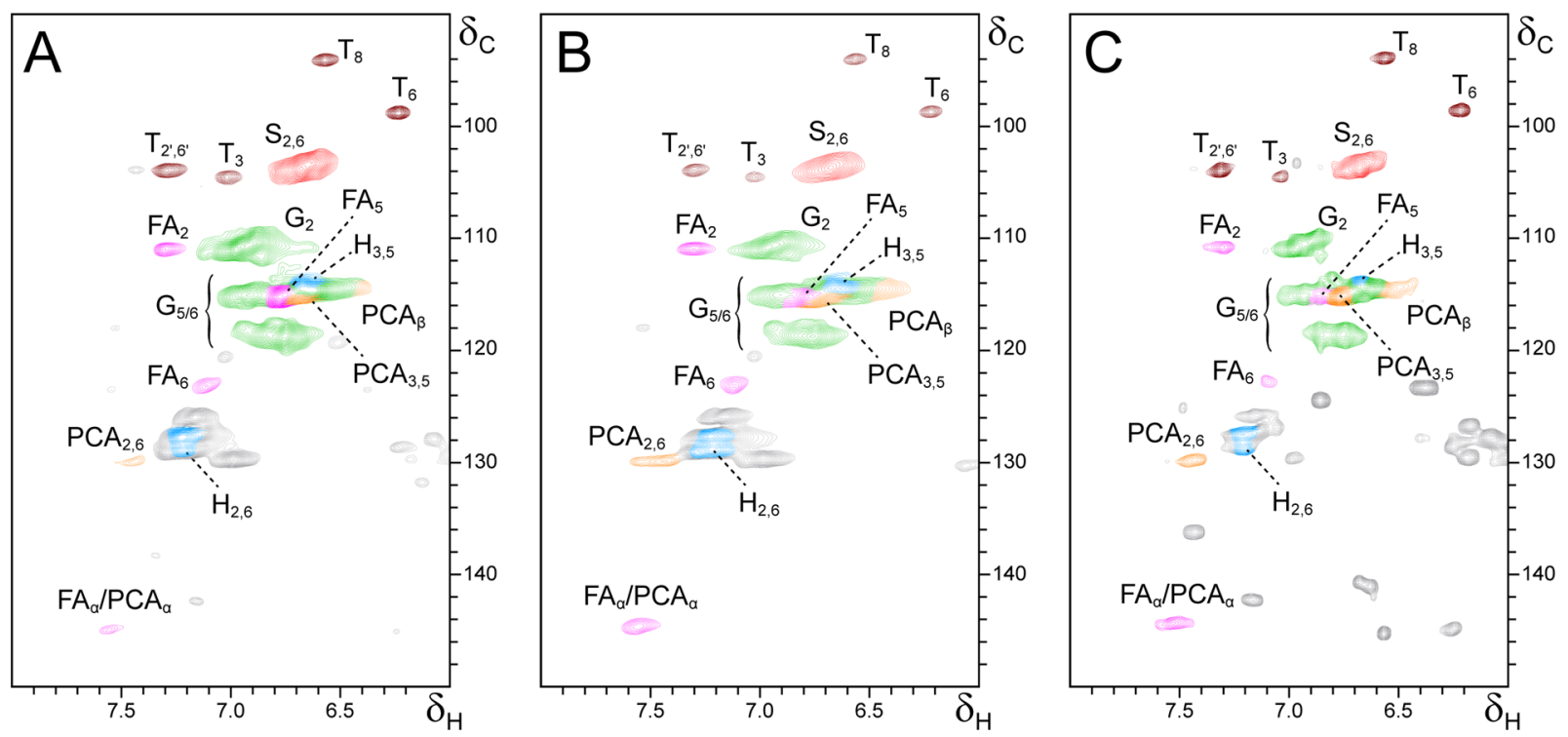

Figure 3. Side-chain $\left(\delta_{\mathrm{C}} / \delta_{\mathrm{H}} 50-90 / 2.5-5.8\right)$ and aromatic/unsaturated $\left(\delta_{\mathrm{C}} / \delta_{\mathrm{H}} 90-160 / 6.0-8.0\right)$ regions in the 2D (HSQC) NMR spectra: (A) MWL; (B) DL; (C) CEL. See Table 4 for signal assignments and Figure 4 for the main lignin structures identified.

esters and cleavage of ether linkages at $\mathrm{C}_{4}$, with subsequent methylation of the formed phenolic groups. The Py/TMAH chromatograms of the BSG lignin preparations are shown in Figure 2. The identities of the compounds released and their relative abundances are listed in Table 3 . It is clearly apparent that Py/TMAH of the different BSG lignin preparations released important amounts of the dimethyl derivatives of $p$ coumaric (21) and ferulic (25) acids, confirming the relatively high amounts of $p$-coumarates and ferulates present in the BSG lignin preparations, as also occurred in the lignin from other grasses. Previous studies have indicated that $p$-coumarates in grasses are acylating the $\gamma-\mathrm{OH}$ of the lignin side chains. ${ }^{16,29,42}$ Ferulates, on the other hand, are an intrinsic part of the lignin structure in grasses, participating in coupling and cross-coupling reactions with other monolignols. ${ }^{16,43,44}$ In all BSG lignin preparations, $p$-coumarates and ferulates were released in nearly similar abundances, with a $p$-coumarates/ferulates ratio around 0.8-1.0. An estimation of the lignin $S / G$ ratio can now be performed upon $\mathrm{Py} / \mathrm{TMAH}$ with more accuracy because $p$ hydroxycinnamates and lignin release clearly differentiated compounds (Table 3 ) and revealed a $S / G$ value in the range 0.4-0.5, similar to that estimated upon Py-GC/MS, by ignoring 4-vinylguaiacol and its respective 4-vinylsyringol and confirming that BSG lignin is enriched in G-lignin units.

Lignin Structural Units and Interunit Linkages As Seen by 2D-NMR. To obtain additional information on the structure of BSG lignin, the different lignin preparations (MWL, DL, and CEL) were analyzed by $2 \mathrm{D}-\mathrm{NMR}$, which 
Table 4. Assignments of the ${ }^{13} \mathrm{C}-{ }^{1} \mathrm{H}$ Correlation Signals for the Lignin Structures Shown in Figure 4 and Observed in the 2D HSQC Spectra (Figure 3) of the MWL, DL, and CEL Preparations Isolated from the BSG Sample

\begin{tabular}{|c|c|c|}
\hline label & $\delta_{\mathrm{C}} / \delta_{\mathrm{H}}$ & assignment \\
\hline $\mathrm{B}_{\beta}$ & $53.1 / 3.43$ & $\begin{array}{l}\mathrm{C}_{\beta}-\mathrm{H}_{\beta} \text { in phenylcoumaran substructures } \\
\text { (B) }\end{array}$ \\
\hline $\mathrm{C}_{\beta}$ & $53.5 / 3.05$ & $\mathrm{C}_{\beta}-\mathrm{H}_{\beta}$ in $\beta-\beta^{\prime}$ resinol substructures $(\mathrm{C})$ \\
\hline$-\mathrm{OCH}_{3}$ & $55.6 / 3.73$ & $\mathrm{C}-\mathrm{H}$ in methoxyls \\
\hline $\mathrm{A}_{\gamma}$ & $\begin{array}{l}59.4 / 3.40 \text { and } \\
3.72\end{array}$ & $\mathrm{C}_{\gamma}-\mathrm{H}_{\gamma}$ in $\beta-O-4^{\prime}$ substructures (A) \\
\hline $\mathrm{C}_{\gamma}$ & $\begin{array}{l}71.0 / 3.83 \text { and } \\
4.19\end{array}$ & $\mathrm{C}_{\gamma}-\mathrm{H}_{\gamma}$ in $\beta-\beta^{\prime}$ resinol substructures (C) \\
\hline $\mathrm{A}_{\alpha(\mathrm{G})}$ & $71.1 / 4.71$ & $\begin{array}{l}\mathrm{C}_{\alpha}-\mathrm{H}_{\alpha} \text { in } \beta-O-4^{\prime} \text { substructures (A) linked } \\
\text { to a } \mathrm{G} \text { unit }\end{array}$ \\
\hline $\mathrm{A}_{\alpha(\mathrm{S})}$ & $71.6 / 4.84$ & $\begin{array}{l}\mathrm{C}_{\alpha}-\mathrm{H}_{\alpha} \text { in } \beta-O-4^{\prime} \text { substructures (A) linked } \\
\text { to an } \mathrm{S} \text { unit }\end{array}$ \\
\hline $\mathrm{A}_{\mathrm{ox} \beta}$ & $82.6 / 5.11$ & $\begin{array}{l}\mathrm{C}_{\beta}-\mathrm{H}_{\beta} \text { in } \alpha \text {-oxidized } \beta \text {-O- } 4^{\prime} \text { substructures } \\
\left(\mathrm{A}_{\mathrm{ox}}\right)\end{array}$ \\
\hline $\mathrm{D}_{\alpha}$ & $83.0 / 4.82$ & $\begin{array}{l}\mathrm{C}_{\alpha}-\mathrm{H}_{\alpha} \text { in } 5-5^{\prime} \text { (dibenzodioxocin) } \\
\text { substructures (D) }\end{array}$ \\
\hline $\mathrm{A}_{\beta(\mathrm{G})}$ & $83.7 / 4.26$ & $\begin{array}{l}\mathrm{C}_{\beta}-\mathrm{H}_{\beta} \text { in } \beta-O-4^{\prime} \text { substructures (A) linked } \\
\text { to a } \mathrm{G} \text { unit }\end{array}$ \\
\hline $\mathrm{C}_{\alpha}$ & $84.7 / 4.64$ & $\mathrm{C}_{\alpha}-\mathrm{H}_{\alpha}$ in $\beta-\beta^{\prime}$ resinol substructures $(\mathrm{C})$ \\
\hline $\mathrm{D}_{\beta}$ & $85.2 / 3.85$ & $\begin{array}{l}\mathrm{C}_{\beta}-\mathrm{H}_{\beta} \text { in } 5-5^{\prime} \text { (dibenzodioxocin) } \\
\text { substructures (D) }\end{array}$ \\
\hline $\mathrm{A}_{\beta(\mathrm{S})}$ & $85.8 / 4.09$ & $\begin{array}{l}\mathrm{C}_{\beta}-\mathrm{H}_{\beta} \text { in } \beta-O-4^{\prime} \text { substructures linked (A) } \\
\text { to an } \mathrm{S} \text { unit }\end{array}$ \\
\hline $\mathrm{B}_{\alpha}$ & $86.8 / 5.43$ & $\begin{array}{l}\mathrm{C}_{\alpha}-\mathrm{H}_{\alpha} \text { in phenylcoumaran substructures } \\
\text { (B) }\end{array}$ \\
\hline $\mathrm{T}_{8}$ & $94.0 / 6.56$ & $\mathrm{C}_{8}-\mathrm{H}_{8}$ in tricin $(\mathrm{T})$ \\
\hline $\mathrm{T}_{6}$ & $98.7 / 6.22$ & $\mathrm{C}_{6}-\mathrm{H}_{6}$ in tricin $(\mathrm{T})$ \\
\hline$S_{2,6}$ & $103.7 / 6.68$ & $\begin{array}{l}\mathrm{C}_{2}-\mathrm{H}_{2} \text { and } \mathrm{C}_{6}-\mathrm{H}_{6} \text { in etherified syringyl } \\
\text { units }(\mathrm{S})\end{array}$ \\
\hline $\mathrm{T}_{2^{\prime}, 6^{\prime}}$ & $103.9 / 7.30$ & $\mathrm{C}_{2^{\prime}, 6^{\prime}}-\mathrm{H}_{2^{\prime}, 6^{\prime}}$ in tricin $(\mathrm{T})$ \\
\hline $\mathrm{T}_{3}$ & $104.5 / 7.03$ & $\mathrm{C}_{3}-\mathrm{H}_{3}$ in tricin $(\mathrm{T})$ \\
\hline $\mathrm{G}_{2}$ & $110.8 / 6.96$ & $\mathrm{C}_{2}-\mathrm{H}_{2}$ in guaiacyl units $(\mathrm{G})$ \\
\hline $\mathrm{F}_{2}$ & $110.9 / 7.30$ & $\mathrm{C}_{2}-\mathrm{H}_{2}$ in ferulate $(\mathrm{FA})$ \\
\hline $\mathrm{PCA}_{\beta} / \mathrm{FA}_{\beta}$ & $114.5 / 6.48$ & $\begin{array}{l}\mathrm{C}_{\beta}-\mathrm{H}_{\beta} \text { in } p \text {-coumarates (PCA) and } \\
\quad \text { ferulates (FA) }\end{array}$ \\
\hline $\mathrm{H}_{3,5}$ & $114.5 / 6.62$ & $\begin{array}{l}\mathrm{C}_{3,5}-\mathrm{H}_{3,5} \text { in } p \text {-hydroxyphenyl units }(\mathrm{H}) \text { and } \\
\text { proteins }\end{array}$ \\
\hline $\mathrm{FA}_{5}$ & $115.1 / 6.76$ & $\mathrm{C}_{5}-\mathrm{H}_{5}$ in ferulate $(\mathrm{FA})$ \\
\hline \multirow[t]{2}{*}{$\mathrm{G}_{5} / \mathrm{G}_{6}$} & $\begin{array}{l}115.0 / 6.74 \text { and } \\
6.94\end{array}$ & $\mathrm{C}_{5}-\mathrm{H}_{5}$ and $\mathrm{C}_{6}-\mathrm{H}_{6}$ in guaiacyl units $(\mathrm{G})$ \\
\hline & $118.8 / 6.79$ & \\
\hline $\mathrm{FA}_{6}$ & $123.2 / 7.12$ & $\mathrm{C}_{6}-\mathrm{H}_{6}$ in ferulates (FA) \\
\hline $\mathrm{H}_{2,6}$ & $128.3 / 7.22$ & $\begin{array}{l}\mathrm{C}_{2,6}-\mathrm{H}_{2,6} \text { in } p \text {-hydroxyphenyl units }(\mathrm{H}) \text { and } \\
\text { proteins }\end{array}$ \\
\hline $\mathrm{PCA}_{2,6}$ & $129.9 / 7.44$ & $\mathrm{C}_{2,6}-\mathrm{H}_{2,6}$ in $p$-coumarates (PCA) \\
\hline $\mathrm{PCA}_{\alpha} / \mathrm{FA}_{\alpha}$ & $144.6 / 7.56$ & $\begin{array}{l}\mathrm{C}_{\alpha}-\mathrm{H}_{\alpha} \text { in } p \text {-coumarates (PCA) and } \\
\text { ferulates (FA) }\end{array}$ \\
\hline
\end{tabular}

provides information on the interunit linkages as well as the composition of the lignin units. The side-chain $\left(\delta_{\mathrm{C}} / \delta_{\mathrm{H}} 50-90 /\right.$ 2.5-5.8) and the aromatic/unsaturated $\left(\delta_{\mathrm{C}} / \delta_{\mathrm{H}} 90-160 / 6.0-\right.$ 8.0) regions of the HSQC NMR spectra of the different lignin preparations are shown in Figure 3. The main lignin crosssignals assigned in the HSQC spectra are listed in Table 4, and the main lignin substructures present are shown in Figure 4.

The side-chain region of the spectra gives important information about the different interunit linkages occurring in the structure of the lignin polymer. The spectra of the different BSG lignin preparations show strong signals from lipids (including linoleic acid), proteins, and carbohydrates; however, they also show intense and characteristic signals for the lignin polymer. Thus, the spectra show prominent signals correspond- ing to $\beta-O-4^{\prime}$ aryl-ether linkages (substructure A). The $\mathrm{C}_{\alpha}-\mathrm{H}_{\alpha}$ correlations in $\beta-O-4^{\prime}$ substructures were observed at $\delta_{\mathrm{C}} / \delta_{\mathrm{H}}$ 71.1/4.71 and 71.6/4.84 for structures linked to $\mathrm{G}$ or $\mathrm{S}$ lignin units, respectively. Likewise, the $\mathrm{C}_{\beta}-\mathrm{H}_{\beta}$ correlations were observed at $\delta_{\mathrm{C}} / \delta_{\mathrm{H}} 83.7 / 4.26$ for $\beta-O-4^{\prime}$ structures linked to $\mathrm{G}$ units and at $\delta_{\mathrm{C}} / \delta_{\mathrm{H}} 85.8 / 4.09$ for $\beta-O-4^{\prime}$ structures linked to $\mathrm{S}$ units. The $\mathrm{C}_{\gamma}-\mathrm{H}_{\gamma}$ correlations of $\beta-O-4^{\prime}$ substructures were observed at $\delta_{\mathrm{C}} / \delta_{\mathrm{H}} 59.4 / 3.40$ and 3.72 , superimposed to other signals. In addition, signals for phenylcoumaran substructures (B) were also found in the spectra of the BSG lignin preparations, the signals for their $\mathrm{C}_{\alpha}-\mathrm{H}_{\alpha}$ and $\mathrm{C}_{\beta}-\mathrm{H}_{\beta}$ correlations being observed at $\delta_{\mathrm{C}} / \delta_{\mathrm{H}} 86.8 / 5.43$ and 53.1/ 3.43, whereas the $\mathrm{C}_{\gamma}-\mathrm{H}_{\gamma}$ correlation overlaps with other $\mathrm{C}_{\gamma}-\mathrm{H}_{\gamma}$ signals around $\delta_{\mathrm{C}} / \delta_{\mathrm{H}} 62 / 3.8$. Resinol substructures (C) were also clearly observed in the spectra, with their $\mathrm{C}_{\alpha}-\mathrm{H}_{\alpha}, \mathrm{C}_{\beta}-\mathrm{H}_{\beta}$, and the double $\mathrm{C}_{\gamma}-\mathrm{H}_{\gamma}$ correlations observed at $\delta_{\mathrm{C}} / \delta_{\mathrm{H}} 84.7 /$ 4.64, 53.5/3.05 and 71.0/3.83 and 4.19. Finally, small signals corresponding to dibenzodioxocin $\left(5^{\prime}-5^{\prime \prime} / \alpha-O-4^{\prime} / \beta-O-4^{\prime \prime}\right.$ linkages) substructures (D) could also be observed in the spectra, with the characteristic $\mathrm{C}_{\alpha}-\mathrm{H}_{\alpha}$ and $\mathrm{C}_{\beta}-\mathrm{H}_{\beta}$ correlations at $\delta_{\mathrm{C}} / \delta_{\mathrm{H}}$ 83.0/4.82 and 85.2/3.85, as well as signals for the $\mathrm{C}_{\beta}-\mathrm{H}_{\beta}$ correlations of $\alpha$-keto- $\beta-O-4^{\prime}$-substructures $\left(\mathrm{A}_{\mathrm{ox}}\right)$ at $\delta_{\mathrm{C}} / \delta_{\mathrm{H}}$ 82.6/5.11.

The main cross-signals in the aromatic/unsaturated region of the HSQC spectra corresponded to the aromatic rings and unsaturated side chains of the different $\mathrm{H}, \mathrm{G}$, and $\mathrm{S}$ lignin units and to $p$-coumarates (PCA) and ferulates (FA) that are associated with the lignin. The $\mathrm{S}$ lignin units presented a strong signal for the $\mathrm{C}_{2,6}-\mathrm{H}_{2,6}$ correlation at $\delta_{\mathrm{C}} / \delta_{\mathrm{H}} 103.7 / 6.68$, whereas the $\mathrm{G}$ lignin units showed different correlation signals for $\mathrm{C}_{2}-\mathrm{H}_{2}\left(\delta_{\mathrm{C}} / \delta_{\mathrm{H}} 110.8 / 6.96\right)$ and $\mathrm{C}_{5}-\mathrm{H}_{5} / \mathrm{C}_{6}-\mathrm{H}_{6}\left(\delta_{\mathrm{C}} / \delta_{\mathrm{H}}\right.$ $115.0 / 6.74$ and 6.94 and $\left.\delta_{\mathrm{C}} / \delta_{\mathrm{H}} 118.8 / 6.79\right)$. Cross-signals corresponding to $\mathrm{C}_{3,5}-\mathrm{H}_{3,5}$ correlations of $\mathrm{H}$ lignin units were observed at $\delta_{\mathrm{C}} / \delta_{\mathrm{H}} 114.5 / 6.62$ overlapping with other lignin signals, whereas the $\mathrm{C}_{2,6}-\mathrm{H}_{2,6}$ correlations at $\delta_{\mathrm{C}} / \delta_{\mathrm{H}} 128.3 / 7.22$ overlapped with strong signals from proteins. Signals corresponding to $p$-coumarate structures (PCA) were clearly observed in the spectra of the isolated lignins. Cross-signals corresponding to the $\mathrm{C}_{2,6}-\mathrm{H}_{2,6}$ at $\delta_{\mathrm{C}} / \delta_{\mathrm{H}} 130.0 / 7.46$ and $\mathrm{C}_{3,5}-$ $\mathrm{H}_{3,5}$ at $\delta_{\mathrm{C}} / \delta_{\mathrm{H}} 115.5 / 6.77$ correlations of the aromatic ring and signals for the correlations of the unsaturated $\mathrm{C}_{\alpha}-\mathrm{H}_{\alpha}$ at $\delta_{\mathrm{C}} / \delta_{\mathrm{H}}$ $144.4 / 7.41$ and $\mathrm{C}_{\beta}-\mathrm{H}_{\beta}$ at $113.5 / 6.27$ of the $p$-coumarate units were observed in this region of the HSQC spectra. Signals corresponding to the $\mathrm{C}_{2}-\mathrm{H}_{2}$ and $\mathrm{C}_{6}-\mathrm{H}_{6}$ correlations of ferulate moieties (FA) were also observed at $\delta_{\mathrm{C}} / \delta_{\mathrm{H}} 111.0 / 7.32$ and 123.3/7.10 in the spectra. The signals corresponding to the unsaturated $\mathrm{C}_{\alpha}-\mathrm{H}_{\alpha}$ and $\mathrm{C}_{\beta}-\mathrm{H}_{\beta}$ correlations overlapped with those of the $p$-coumarate units. Moreover, the signals for the $\mathrm{C}_{\beta}-\mathrm{H}_{\beta}$ correlations of $p$-coumarates and ferulates indicated that the carboxylic groups were not in free but in ester form. Interestingly, in this region of the HSQC spectra, it was also possible to detect the two distinctive and typical signals at $\delta_{\mathrm{C}} /$ $\delta_{\mathrm{H}} 94.1 / 6.56$ and $98.7 / 6.22$ corresponding to the $\mathrm{C}_{8}-\mathrm{H}_{8}$ and $\mathrm{C}_{6}-\mathrm{H}_{6}$ correlations of tricin $(\mathrm{T}){ }^{28}$ a flavone that is widely found and is apparently incorporated into the lignin structure in some grasses, ${ }^{28,45,46}$ and that also occur in the lignin of other monocotyledons, such as coconut coir. ${ }^{30}$ The HSQC spectra also show the $\mathrm{C}_{3}-\mathrm{H}_{3}$ correlation of tricin at $\delta_{\mathrm{C}} / \delta_{\mathrm{H}} 104.5 / 7.03$, whereas the correlations for $\mathrm{C}_{2^{\prime}}-\mathrm{H}_{2^{\prime}}$ and $\mathrm{C}_{6^{\prime}}-\mathrm{H}_{6^{\prime}}$ are observed at $\delta_{\mathrm{C}} / \delta_{\mathrm{H}} 103.9 / 7.30$. Tricin arises from a different pathway than the usual monolignols, but seems to act as a lignin monomer in grasses. Tricin cannot couple with other tricins, so it can only undergo cross-coupling with monolignols and must be present 
<smiles>COc1cc(C)cc(C)c1OC(CO)[C@@H](O)c1cc(C)cc(OC)c1OC</smiles>

A<smiles>COc1cc(C(=O)C(OC(C)C)C(=O)c2cc(C)c(OC)c(OC)c2)c(C)cc1O</smiles>

A ox<smiles>CCOc1c(C)cc(C2Oc3c(OC)cc(C)cc3-c3cc(C)cc(OC)c3OC2C(I)CO)cc1OC</smiles>

D<smiles>COc1cc(C2Oc3c(OC)cc(C)cc3C2CO)cc(OC)c1OC</smiles>

B<smiles>CCOc1c(C)cc(C2OCC3C(c4cc(OC)c(OC)c(OC)c4)COC23)cc1OC</smiles>

C<smiles>CCOC(=O)Cc1ccc(O)cc1</smiles>

PCA

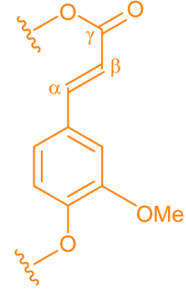

FA<smiles>COc1ccc(C(O)C(C)C)cc1</smiles>

H

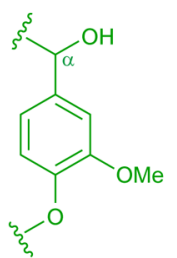

G<smiles>CCOc1cc(-c2cc(=O)c3c(O)cc(O)cc3o2)cc(OC)c1OC</smiles><smiles>CCC(O)c1cc(OC)c(OC)c(OC)c1</smiles>

S

Figure 4. Main structures present in the lignin preparations from brewer's spent grain: (A) $\beta$-O- $4^{\prime}$ alkyl-aryl ethers; $\left(\mathrm{A}_{\text {ox }}\right) \mathrm{C}_{\alpha}$-oxidized $\beta$-O-4' structures; (B) phenylcoumarans; (C) resinols; (D) dibenzodioxocins; (PCA) p-coumarates; (FA) ferulates; (H) p-hydroxyphenyl units; (G) guaiacyl units; (S) syringyl units; $(\mathrm{T})$ tricin.

at the start of lignification acting as the initiation site. The incorporation of tricin into the lignin polymer through $4-O-\beta$ ether linkages has already been reported. ${ }^{29}$

The relative abundances of the main lignin interunit linkages and the molar abundances of the different lignin units $(H, G$, and $S$ ), $p$-hydroxycinnamates ( $p$-coumarates and ferulates), and tricin, all estimated from volume integration of the corresponding cross-signals in the HSQC spectra, are shown in Table 5. The three lignin preparations gave similar results, indicating that they might be considered as representative of the native lignin in BSG. The main substructure present in the lignin of BSG was the $\beta-O-4^{\prime}$ alkyl-aryl ether ( $\mathrm{A}$ and $\mathrm{A}_{\mathrm{ox}}$ ), which accounts for $77-79 \%$ of all interunit linkages, followed by $\beta-5^{\prime}$ phenylcoumaran substructures (B) that involved $11-13 \%$ of all linkages and lower amounts of $\beta-\beta^{\prime}$ resinol substructures (C) with 5-6\%, and dibenzodioxocins with $3-5 \%$, depending on the lignin preparation. The exact determination of the $\mathrm{H}: \mathrm{G}: \mathrm{S}$ composition of the BSG lignin preparations was not possible due to the high amounts of proteins present in the lignin preparations, which impairs obtaining an accurate volume integral of the $\mathrm{C}_{2,6}-\mathrm{H}_{2,6}$ correlation of the $\mathrm{H}$ units. Therefore, the abundance of $\mathrm{H}$ lignin units is overestimated. However, and despite this limitation, the calculation of the $S / G$ ratio can be performed with more accuracy because the characteristic signals are well resolved. The lignin $\mathrm{S} / \mathrm{G}$ ratio determined upon $2 \mathrm{D}$ NMR gave a value of 0.4 , similar to that obtained upon Py-GC/ MS and Py/TMAH, and confirmed that the BSG lignin is enriched in $\mathrm{G}$ units. With regard to the content of $p$ hydroxycinnamates, a higher abundance of ferulates than $p$ coumarates was observed in all lignin preparations, with $p$ coumarates accounting for $5-6 \%$ and ferulates accounting for $7-10 \%$ of the total lignin units. Finally, tricin units account for $5-8 \%$ of total lignin units, with the highest abundance in the CEL preparation.

Lignin Acylation with $p$-Coumarates and Acetates As Seen by 2D-NMR and DFRC. Whereas ferulates are an intrinsic part of the lignin structure in grasses, participating in coupling and cross-coupling reactions with other monolignols and producing a diversity of linkages, $p$-coumarates are always present acylating the $\gamma$-carbon of the lignin side chain. ${ }^{16,28,42}$ However, the characteristic $\mathrm{C}_{\gamma}-\mathrm{H}_{\gamma}$ correlations of $\gamma$-acylated lignin units at $\delta_{\mathrm{C}} / \delta_{\mathrm{H}} 62.7 / 3.83-4.30$ could not be clearly observed in the HSQC spectra of the different BSG lignin preparations due to overlapping with other signals. In this sense, and to prove that the $p$-coumarates present in BSG lignin are also acylating the $\gamma$-carbon of the lignin side chain, we 
Table 5. Structural Characteristics (Lignin Interunit Linkages, Aromatic Units, $p$-Coumarates and Ferulates, and Tricin Content) from Integration of ${ }^{13} \mathrm{C}-{ }^{1} \mathrm{H}$ Correlation Signals in the HSQC Spectra of the MWL, DL, and CEL Lignin Preparations Isolated from the BSG Sample

\begin{tabular}{|c|c|c|c|}
\hline & MWL & $\mathrm{DL}$ & CEL \\
\hline \multicolumn{4}{|l|}{ lignin interunit linkages $(\%)^{a}$} \\
\hline$\beta-O-4^{\prime}$ aryl ethers (A) & 72 & 75 & 75 \\
\hline $\mathrm{C} \alpha$-oxidized $\beta-O-4^{\prime}$ aryl ethers $\left(\mathrm{A}_{\mathrm{ox}}\right)$ & 5 & 4 & 3 \\
\hline phenylcoumarans (B) & 12 & 11 & 13 \\
\hline resinols $(\mathrm{C})$ & 6 & 5 & 6 \\
\hline dibenzodioxocins (D) & 5 & 5 & 3 \\
\hline \multicolumn{4}{|l|}{ lignin aromatic units ${ }^{b}$} \\
\hline $\mathrm{H}(\%)^{c}$ & 24 & 32 & 20 \\
\hline $\mathrm{G}(\%)$ & 56 & 50 & 59 \\
\hline S (\%) & 20 & 18 & 21 \\
\hline $\mathrm{S} / \mathrm{G}$ ratio & 0.4 & 0.4 & 0.4 \\
\hline \multicolumn{4}{|l|}{$p$-hydroxycinnamates ${ }^{d}$} \\
\hline$p$-coumarates $(\%)$ & 5 & 5 & 6 \\
\hline ferulates (\%) & 7 & 9 & 10 \\
\hline$p$-coumarates/ferulates ratio & 0.7 & 0.6 & 0.6 \\
\hline $\operatorname{tricin}^{d}$ & 5 & 5 & 8 \\
\hline
\end{tabular}

${ }^{a}$ Expressed as a fraction of the total lignin interunit linkage types A-D. ${ }^{b}$ Molar percentages $(H+G+S=100)$. ${ }^{c}$ Overestimated due to the presence of proteins. ${ }^{d}$ Molar content as percentage of lignin content $(\mathrm{H}+\mathrm{G}+\mathrm{S}=100)$.

performed $\mathrm{HMBC}$ experiments that correlate protons with carbons separated by two or three bonds. Figure 5 shows the section of the HMBC of the MWL preparation isolated from BSG with the correlations of the carbonyl carbons of the groups acylating the lignin $\gamma$-OH. The correlations of the carbonyl carbon at $166.0 \mathrm{ppm}$ with the $\alpha$-protons of $p$-coumarate esters (at $7.56 \mathrm{ppm}$ ) indicate that they belong to $p$-coumarate esters, but more important, the correlations of this carbonyl carbon with the protons at $4.08 \mathrm{ppm}^{28,42}$ definitively confirm that $p$ coumarates in BSG lignin are acylating the $\gamma$-position of the lignin side chains, as usually occurs in all grasses. However, the HBMC spectrum did not present any correlation for acetate groups (at $169.8 \mathrm{ppm}$ ) acylating the lignin side chain, despite the acetates having been widely found acylating the $\gamma-\mathrm{OH}$ in the lignins of many plants, including grasses. ${ }^{28,29,34-36,47}$ This result seems to indicate that the extent of lignin $\gamma$-acetylation, if any, should be very low.
Further information about the acylation of the $\gamma-\mathrm{OH}$ of the lignin side chain was obtained from DFRC, a chemical degradative method that cleaves $\alpha$ - and $\beta$-ether bonds but leaves $\gamma$-esters intact. ${ }^{31-33}$ The chromatogram of the DFRC degradation products of the MWL preparation is shown in Figure 6. The MWL from BSG released the cis- and transisomers of guaiacyl ( $c \mathrm{G}$ and $t \mathrm{G}$ ) and syringyl ( $c S$ and $t S$ ) lignin monomers (as their acetylated derivatives), arising from normal, non- $\gamma$ - $p$-coumaroylated $\beta$-ethers in lignin. Only minor amounts of $\gamma$-p-coumaroylated syringyl $\left(t S_{p c}\right)$ monomers could be detected in the chromatogram $(<0.7 \%$ of the peak molar area of all lignin units) despite the significant amounts of $p$ coumarates present in this lignin ( $5 \%$ with respect to the total lignin aromatic units, as estimated by $2 \mathrm{D}-\mathrm{NMR}$ in Table 5) and the fact that $p$-coumarates are acylating the $\gamma$-carbon, as observed by HMBC. No traces of $\gamma$-p-coumaroylated guaiacyl $\left(c \mathrm{G}_{p c}\right.$ and $t \mathrm{G}_{p c}$ ) lignin units could be found in the chromatogram despite this lignin being enriched in $G$ lignin units, confirming that $p$-coumarates preferentially acylate $S$ lignin units, as usually occurs in grasses. ${ }^{16,29,42}$ Similar results were recently observed in the lignin from wheat straw, where neither traces of $\gamma$ - $p$-coumaroylated syringyl nor guaiacyl conjugates were released, despite $p$-coumarates being attached to the $\gamma$ carbon, as clearly revealed by NMR. ${ }^{28}$ This finding seems to indicate that, as also occurred in the lignin of wheat straw, $p$ coumarate groups are mostly attached to the lignin $\gamma-\mathrm{OH}$ in condensed lignin substructures that are not amenable to DFRC analysis.

The DFRC degradation method originally developed does not allow the analysis of natively acetylated lignin units because the degradation products are acetylated during the procedure. However, with appropriate modification of the original protocol by replacing acetylating reagents with propionylating ones, it is possible to obtain information about the presence of acetate groups originally acylating the $\gamma-\mathrm{OH}$ in lignin. ${ }^{34-36}$ The results from this analysis indicated only a very minor extent of $\gamma$ acetylation of this lignin (undetectable by HMBC), which takes place predominantly on syringyl units $(6 \%$ of $S$ lignin units are acetylated), whereas only traces of acetylated guaiacyl units were detected ( $1 \%$ of $\mathrm{G}$ lignin units are acetylated).

In conclusion, the content and structure of the lignin from BSG have been thoroughly studied for the first time in the present work. Three different lignin preparations (MWL, DL, and CEL) were isolated and characterized in detail by different analytical methodologies (Py-GC/MS, 2D-NMR, DFRC). The

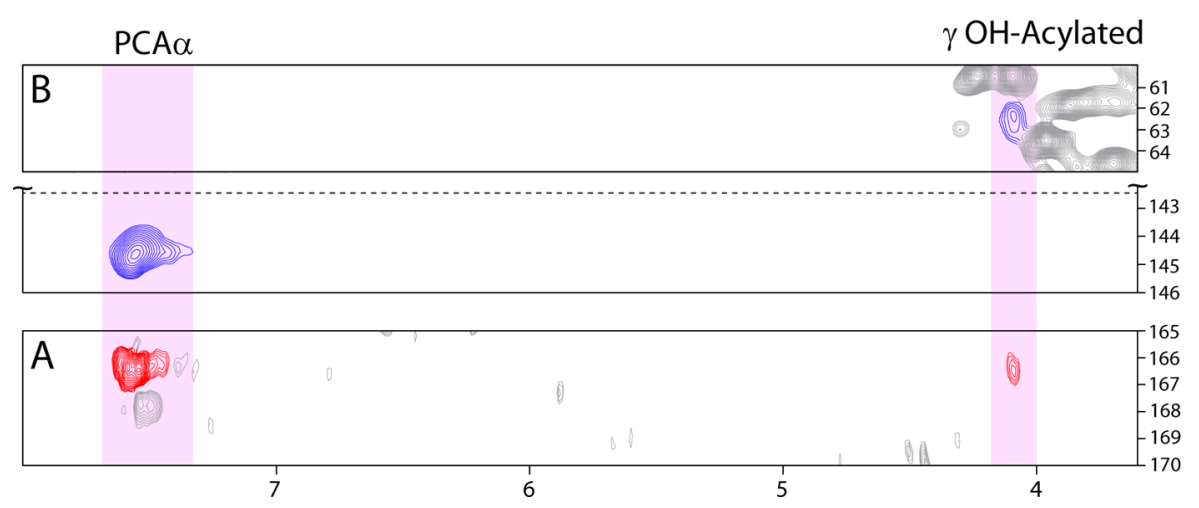

Figure 5. Section of the HMBC spectrum $\left(\delta_{\mathrm{C}} / \delta_{\mathrm{H}} 165-170 / 3.5-8.0\right)$ of the MWL preparation isolated from BSG showing the main correlations for the carbonyl carbon of $p$-coumarates acylating the $\gamma$-position of the lignin side chain (A). Appropriate sections of the HSQC spectrum showing the $\mathrm{C}_{\gamma}-\mathrm{H}_{\gamma}$ correlations of the acylated lignin $\gamma$-carbon $\left(\delta_{\mathrm{C}} 60-65\right)$ and the $\mathrm{C}_{\alpha}-\mathrm{H}_{\alpha}$ correlations of $p$-coumarates $\left(\delta_{\mathrm{C}} 142-146\right)$ are also shown $(\mathrm{B})$. 


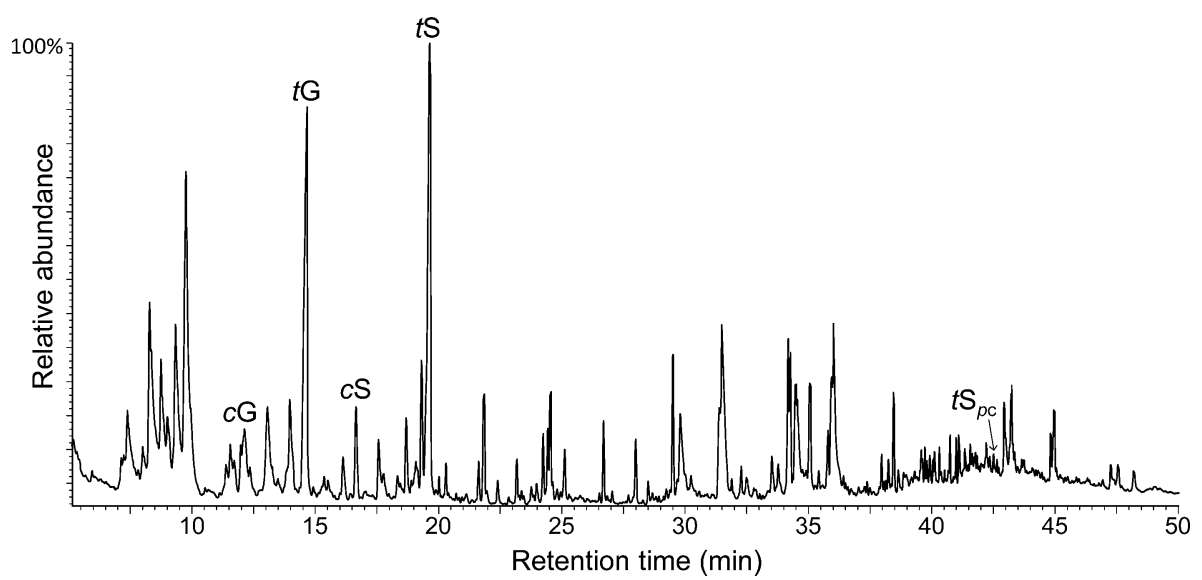

Figure 6. Chromatogram (GC-TIC) of the DFRC degradation products from the MWL preparation isolated from the BSG. $c \mathrm{G}, t \mathrm{G}, c \mathrm{~S}$, and $t \mathrm{~S}$ are the normal cis- and trans-coniferyl and -sinapyl alcohol (guaiacyl and syringyl) monomers (as their acetate derivatives). $t S_{p c}$ is the trans-sinapyl $p$ coumarate (as its acetate derivative).

analyses of these lignin preparations gave similar results and indicated that this lignin presents a strong predominance of $\mathrm{G}$ lignin units ( $\mathrm{S} / \mathrm{G}$ ratio of $0.4-0.5)$ with some amounts of associated $p$-coumarates and ferulates. The main lignin substructures present in BSG include $\beta-O-4^{\prime}$ alkyl-aryl ethers (77-79\% of all interunit linkages), followed by $\beta-5^{\prime}$ phenylcoumarans $(11-13 \%)$ and minor amounts of $\beta-\beta^{\prime}$ resinols $(5-$ $6 \%)$ and $5-5^{\prime}$ dibenzodioxocins (3-5\%). Finally, we also found that the flavone tricin is incorporated into the BSG lignin, as seems to occur in all grasses. The comprehensive understanding of the composition and structure of BSG lignin accomplished here will help development of lignin-based highadded-value products from this agro-industrial waste material and design of effective deconstruction strategies for biorefinery purposes.

\section{AUTHOR INFORMATION}

\section{Corresponding Author}

*(J.C.d.R.) Phone: +34-95-4624711. Fax: +34-95-4624002. Email: delrio@irnase.csic.es.

\section{Funding}

This study has been funded by the Spanish Project AGL201125379 (cofinanced by FEDER funds) and the EU Project LIGNODECO (KBBE-244362). J.R. thanks the CSIC for a JAE-DOC contract of the program "Junta para la Ampliación de Estudios” cofinanced by Fondo Social Europeo (FSE). P.P. thanks the Spanish Ministry of Science and Innovation for an FPI fellowship.

Notes

The authors declare no competing financial interest.

\section{ACKNOWLEDGMENTS}

We thank Prof. Craig B. Faulds (INRA, Marseille, France) for providing the BSG sample analyzed in this study. We also thank Dr. Manuel Angulo (CITIUS, University of Seville) for performing the NMR analyses.

\section{REFERENCES}

(1) Mussatto, S. I.; Dragone, G.; Roberto, I. C. Brewers' spent grain: generation, characteristics and potential applications. J. Cereal Sci. 2006, 43, 1-14.

(2) Aliyu, S.; Bala, M. Brewer's spent grain: a review of its potentials and applications. Afr. J. Biotechnol. 2011, 10, 324-331.
(3) Santos, M.; Jiménez, J. J.; Bartolomé, B.; Gómez-Cordovés, C.; del Nozal, M. J. Variability of brewer's spent grain within a brewery. Food Chem. 2003, 80, 17-21.

(4) Robertson, J. A.; I'Anson, K. J. A.; Treimo, J.; Faulds, C. B.; Brocklehurst, T. F.; Eijsink, V. G. H.; Waldron, K. W. Profiling brewers' spent grain for composition and microbial ecology at the site of production. LWT-Food Sci. Technol. 2010, 43, 890-896.

(5) Niemi, P.; Tamminen, T.; Smeds, A.; Viljanen, K.; Ohra-aho, T.; Holopainen-Mantila, U.; Faulds, C. B.; Poutanen, K.; Buchert, J. Characterization of lipids and lignans in brewer's spent grain and its enzymatically extracted fraction. J. Agric. Food Chem. 2012, 60, 99109917.

(6) del Río, J. C.; Prinsen, P.; Gutiérrez, A. Chemical composition of lipids in brewer's spent grain: a promising source of valuable phytochemicals. J. Cereal Sci. 2013, 58, 248-254.

(7) Mussatto, S. I.; Fernandes, M.; Roberto, I. C. Lignin recovery from brewer's spent grain black liquor. Carbohydr. Polym. 2007, 70, 218-223.

(8) Wilkinson, S.; Smart, K. A.; Cook, D. J. Optimisation of alkaline reagent based chemical pre-treatment of Brewers spent grains for bioethanol production. Ind. Crops Prod. 2014, 62, 219-227.

(9) Faulds, C. B.; Mandalari, G.; LoCurto, R.; Bisignano, G.; Waldron, K. W. Arabinoxylan and mono- and dimeric ferulic acid release from brewer's grain and wheat bran by feruloyl esterases and glycosyl hydrolases from Humicola insolens. Appl. Microbiol. Biotechnol. 2004, 64, 644-650.

(10) Hernanz, D.; Nuñez, V.; Sancho, A. I.; Faulds, C. B.; Williamson, G.; Bartolomé, B.; Gómez-Cordovés, C. Hydroxycinnamic acids and ferulic acid dehydrodimers in barley and processed barley. $J$. Agric. Food Chem. 2001, 49, 4884-4888.

(11) Mussatto, S. I.; Dragone, G.; Roberto, I. C. Ferulic and $p$ coumaric acids extraction by alkaline hydrolysis of brewer's spent grain. Ind. Crops Prod. 2007, 25, 231-237.

(12) Aura, A.-M.; Niemi, P.; Mattila, I.; Niemelä, K.; Smeds, A.; Tamminen, T.; Faulds, C. B.; Buchert, J.; Poutanen, K. Release of small phenolic compounds from brewer's spent grain and its lignin fractions by human intestinal microbiota in vitro. J. Agric. Food Chem. 2013, 61, 9744-9753.

(13) Niemi, P.; Aura, A.-M.; Maukonen, J.; Smeds, A. I.; Mattila, I.; Niemelä, K.; Tamminen, T.; Faulds, C. B.; Buchert, J.; Poutanen, K. Interactions of a lignin-rich fraction from brewer's spent grain with gut microbiota in vitro. J. Agric. Food Chem. 2013, 61, 6754-6762.

(14) Boerjan, W.; Ralph, J.; Baucher, M. Lignin biosynthesis. Annu. Rev. Plant Biol. 2003, 54, 519-549.

(15) Ralph, J.; Lundquist, K.; Brunow, G.; Lu, F.; Kim, H.; Schatz, P. F.; Marita, J. M.; Hatfield, R. D.; Ralph, S. A.; Christensen, J. H.; Boerjan, W. Lignins: natural polymers from oxidative coupling of 4hydroxyphenylpropanoids. Phytochem. Rev. 2004, 3, 29-60. 
(16) Ralph, J. Hydroxycinnamates in lignification. Phytochem. Rev. 2010, 9, 65-83.

(17) Björkman, A. Studies on finely divided wood. Part I. Extraction of lignin with neutral solvents. Sven. Papperstidn. 1956, 59, 477-485.

(18) Evtuguin, D. V.; Neto, C. P.; Silva, A. M. S.; Domingues, P. M.; Amado, F. M. L.; Robert, D.; Faix, O. Comprehensive study on the chemical structure of dioxane lignin from plantation Eucalyptus globulus wood. J. Agric. Food Chem. 2001, 49, 4252-4261.

(19) Chang, H.-M.; Cowling, E. B.; Brown, W.; Adler, E.; Miksche, G. Comparative studies on cellulolytic enzyme lignin and milled wood lignin of sweetgum and spruce. Holzforschung 1975, 29, 153-159.

(20) Faulds, C. B.; Robertson, J. A.; Waldron, K. W. Effect of pH on the solubilization of brewers' spent grain by microbial carbohydrases and proteases. J. Agric. Food Chem. 2008, 56, 7038-7043.

(21) Tappi. Tappi Test Methods 2004-2005; Tappi Press: Norcoss, GA, USA, 2004.

(22) Darvill, A. G.; McNeil, M.; Albersheim, P.; Delmer, D. The primary cell-walls of flowering plants. In The Biochemistry of Plants; Tolbert, N., Ed.; Academic Press: New York, 1980; pp 91-162.

(23) Browning, B. L. Methods of Wood Chemistry; Wiley-Interscience: New York, 1967.

(24) Faix, O.; Meier, D.; Fortmann, I. Thermal degradation products of wood. Gas chromatographic separation and mass spectrometric characterization of monomeric lignin-derived products. Holz RohWerkst. 1990, 48, 351-354.

(25) Ralph, J.; Hatfield, R. D. Pyrolysis-GC-MS characterization of forage materials. J. Agric. Food Chem. 1991, 39, 1426-1437.

(26) Bocchini, P.; Galletti, G. C.; Camarero, S.; Martínez, A. T. Absolute quantitation of lignin pyrolysis products using an internal standard. J. Chromatogr., A 1997, 773, 227-232.

(27) Ralph, S. A.; Ralph, J.; Landucci, L. NMR Database of Lignin and Cell Wall Model Compounds; U.S. Forest Products Laboratory: Madison, WI, USA; http://ars.usda.gov/Services/docs.htm?docid= 10491) (accessed January 2009).

(28) del Río, J. C.; Rencoret, J.; Prinsen, P.; Martínez, Á. T.; Ralph, J.; Gutiérrez, A. Structural characterization of wheat straw lignin as revealed by analytical pyrolysis, $2 \mathrm{D}-\mathrm{NMR}$, and reductive cleavage methods. J. Agric. Food Chem. 2012, 60, 5922-5935.

(29) del Río, J. C.; Prinsen, P.; Rencoret, J.; Nieto, L.; JiménezBarbero, J.; Ralph, J.; Martínez, Á. T.; Gutiérrez, A. Structural characterization of the lignin in the cortex and pith of elephant grass (Pennisetum purpureum) stems. J. Agric. Food Chem. 2012, 60, 36193634.

(30) Rencoret, J.; Ralph, J.; Marques, G.; Gutiérrez, A.; Martínez, Á. T.; del Río, J. C. Structural characterization of lignin isolated from coconut (Cocos nucifera) coir fibers. J. Agric. Food Chem. 2013, 61, 2434-2445.

(31) Lu, F.; Ralph, J. The DFRC method for lignin analysis. 1. A new method for $\beta$-aryl ether cleavage: lignin model studies. J. Agric. Food Chem. 1997, 45, 4655-4660.

(32) Lu, F.; Ralph, J. The DFRC method for lignin analysis. 2. Monomers from isolated lignin. J. Agric. Food Chem. 1998, 46, 547552.

(33) Lu, F.; Ralph, J. Detection and determination of $p$ coumaroylated units in lignins. J. Agric. Food Chem. 1999, 47, 19881992.

(34) Ralph, J.; Lu, F. The DFRC method for lignin analysis. 6. A simple modification for identifying natural acetates in lignin. J. Agric. Food Chem. 1998, 46, 4616-4619.

(35) del Río, J. C.; Marques, G.; Rencoret, J.; Martínez, A. T.; Gutiérrez, A. Occurrence of naturally acetylated lignin units. J. Agric. Food Chem. 2007, 55, 5461-5468.

(36) del Río, J. C.; Rencoret, J.; Marques, G.; Gutiérrez, A.; Ibarra, D.; Santos, J. I.; Jiménez-Barbero, J.; Zhang, L.; Martínez, A. T. Highly acylated (acetylated and/or p-coumaroylated) native lignins from diverse herbaceous plants. J. Agric. Food Chem. 2008, 56, 9525-9534. (37) Crestini, C.; Melone, F.; Sette, M.; Saladino, R. Milled wood lignin: a linear oligomer. Biomacromolecules 2011, 12, 3928-3935.
(38) Capanema, E.; Ballakshin, M.; Katahira, R.; Chang, H.-M.; Jameel, H. How well do MWL and CEL preparations represent the whole hardwood lignin? J. Wood Chem. Technol. 2015, 35, 17-26.

(39) Fujimoto, A.; Matsumoto, Y.; Chang, H.-M.; Meshitsuka, G. Quantitative evaluation of milling effects on lignin structure during the isolation process of milled wood lignin. J. Wood Sci. 2005, 51, 89-91.

(40) del Río, J. C.; Gutiérrez, A.; Rodríguez, I. M.; Ibarra, D.; Martínez, Á. T. Composition of non-woody plant lignins and cinnamic acids by Py-GC/MS, Py/TMAH and FT-IR. J. Anal. Appl. Pyrol. 2007, $79,39-46$.

(41) del Rio, J. C.; Martin, F.; Gonzalez-Vila, F. J. Thermally assisted hydrolysis and alkylation as a novel pyrolytic approach for the structural characterization of natural biopolymers and geomacromolecules. Trends Anal. Chem. 1996, 15, 70-79.

(42) Ralph, J.; Hatfield, R. D.; Quideau, S.; Helm, R. F.; Grabber, J. H.; Jung, H.-J. G. Pathway of $p$-coumaric acid incorporation into maize lignin as revealed by NMR. J. Am. Chem. Soc. 1994, 116, 9448-9456.

(43) Grabber, J. H.; Hatfield, R. D.; Ralph, J.; Zon, J.; Amrhein, N. Ferulate cross-linking in cell walls isolated from maize cell suspensions. Phytochemistry 1995, 40, 1077-1082.

(44) Ralph, J.; Grabber, J. H.; Hatfield, R. D. Lignin-ferulate crosslinks in grasses: active incorporation of ferulate polysaccharide esters into ryegrass lignins. Carbohydr. Res. 1995, 275, 167-178.

(45) Wen, J.-L.; Sun, S.-L.; Xue, B.-L.; Sun, R.-C. Quantitative structural characterization of the lignins from the stem and pith of bamboo (Phyllostachys pubescens). Holzforschung 2013, 67, 613-627.

(46) You, T.-T.; Mao, J.-Z.; Yuan, T.-Q.; Wen, J.-L.; Xu, F. Structural elucidation of the lignins from stems and foliage of Arundo donax Linn. J. Agric. Food Chem. 2013, 61, 5361-5370.

(47) Ralph, J. An unusual lignin from kenaf. J. Nat. Prod. 1996, 59, $341-342$. 